\title{
Groundwater estuaries of salt lakes: buried pools of endemic biodiversity on the western plateau, Australia
}

\section{W. F. Humphreys $\cdot$ C. H. S. Watts ·}

S. J. B. Cooper $\cdot$ R. Leijs

Published online: 9 July 2009

(C) Springer Science+Business Media B.V. 2009

\section{Erratum to: Hydrobiologia (2009) 626:79-95 DOI 10.1007/s10750-009-9738-4}

Figure 6 in this article is wrong (it is a duplicate of Fig. 4). The correct Fig. 6 is shown here. We apologise for this error.

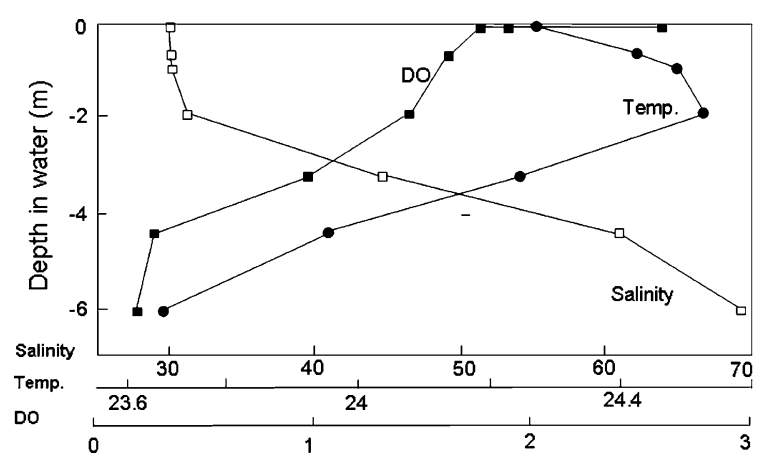

Fig. 6 Depth profile through the water column in a mineral exploration bore (designated bore 267) at the Lake Urumurdah calcrete aquifer. Salinity as TDS $\left(\mathrm{g} \mathrm{l}^{-1}\right)$, temperature $\left({ }^{\circ} \mathrm{C}\right)$ and dissolved oxygen (DO $\mathrm{mg} \mathrm{l}^{-1}$ ) (after Humphreys, 2006). This site supports stygal oniscideans, bathynellaceans, harpacticoid copepods, amphipods and dytiscid diving beetles
The online version of the original article can be found under doi:10.1007/s10750-009-9738-4.

W. F. Humphreys ( $₫)$

Terrestrial Invertebrates, Western Australian Museum, Locked Bag 49, Welshpool DC, WA 6986, Australia e-mail: Bill.Humphreys@museum.wa.gov.au

C. H. S. Watts · S. J. B. Cooper - R. Leijs Evolutionary Biology Unit, South Australian Museum, North Terrace, Adelaide, SA 5000, Australia

\section{S. J. B. Cooper · R. Leijs}

Australian Centre for Evolutionary Biology and

Biodiversity, The University of Adelaide, Adelaide,

SA 5005, Australia 